\title{
Seismic Upgrading of Steel Moment-Resisting Frames by Means of Friction Devices
}

\author{
Esra Mete Güneyisi ${ }^{1}$, Mario D'Aniello ${ }^{2 *}$ and Raffaele Landolfo ${ }^{2}$ \\ ${ }^{I}$ Department of Civil Engineering, University of Gaziantep, 27310, Gaziantep, Turkey; ${ }^{2}$ Department of Structures for \\ Engineering and Architecture, University of Naples "Federico II", Naples, Italy
}

\begin{abstract}
In recent decades, several passive energy dissipation systems have been conceived in order to minimize the damage in structural and non-structural components of either new or existing buildings. In this study, the use of friction damped tension-compression diagonal braces for seismic upgrading of a steel moment resisting frames is investigated. To this aim, nonlinear time history analyses have been carried out on a set of representative frames with and without friction damped braces. In the nonlinear time history analyses, two sets of natural accelerograms compatible with seismic hazard levels of $10 \%$ and $2 \%$ probability of exceedance in 50 years have been considered. Under these records, the structural response has been comparatively investigated in terms of the maximum inter-storey drift ratio, maximum storey acceleration, residual drift ratio and displacement demand for the friction device. The results clearly highlighted that the application of friction damped braces allows reducing the damages to the main structural elements, thus significantly improving the seismic behaviour of the frame.
\end{abstract}

Keywords: Friction device, nonlinear time history analysis, passive energy dissipation systems, seismic response, steel frame.

\section{INTRODUCTION}

The widespread structural damage experienced in the steel moment resisting frames (MRFs) during both the 1994 Northridge and the 1995 Kobe earthquakes demonstrates the need for limiting the inter-storey displacements, in order to mitigate the issues due to P-Delta effects, at global level, and the fracture of joints, at local level [1-5]. In order to prevent or reduce seismic damages from the main structural systems, several passive dissipative devices have been extensively studied in the last thirty years [6-21].

Among such devices, friction dampers can be considered as one of the most efficient for reducing the structural damage caused by earthquakes [22-24]. Compared with velocitydependent devices such as viscous and viscoelastic dampers, friction dampers can provide sufficient initial stiffness as well as energy-dissipation capacity [25].

Friction devices, typical view of which is given in Fig. (1) [26], use the resistance developed between moving solid interfaces clamped by means of high strength bolts to dissipate a large amount of the input energy. Since the sliding force does not depend on the velocity of the applied excitation, the entity of the applied displacement and the slip force influence the amount of dissipated energy. Hence, both monotonic and cyclic behaviour of this category of dampers can be described by means of a rigid-plastic response. This aspect is very convenient from a design point of view, because designer has to fix only the slip force and the stroke that the devices have to provide. The former depends on the

\footnotetext{
*Address correspondence to this author at the Department of Structures for Engineering and Architecture, University of Naples "Federico II", Naples, Italy; Tel: (+39) 081.2538917; E-mail: mdaniel@unina.it
}

value of the clamping load applied to the surfaces in contact and on the friction coefficient. The type of materials and the quality of surface finishing of the layers in contact are the main parameters characterizing the friction coefficient [27]. As also highlighted by [27] the main advantage of friction devices for seismic application is that they can work as displacement reducers under service conditions, and energy dissipators under severe seismic actions. Moreover, friction dampers are not vulnerable to the thermal effects and have a reliable performance with the stable hysteretic behaviour $[28,29]$. Several experimental researches have been carried out to investigate the energy dissipating capacity of friction dampers and to propose a proper design procedure $[28,30-$ 35]. In the literature, there are also recent numerical studies in which structural analysis and design of friction damped structures have been examined [23, 36-44]. For example, in the study of Pall and Marsh [30], a new approach for improving the earthquake resistance of framed structures was developed. They proposed sliding friction devices in the bracing system of structures. It was concluded that the proposed friction devices acted as safety valves and structural dampers. It was also reported that such device might be appropriately included in existing framed buildings to upgrade their seismic behaviour. Li and Reinhorn [37] carried out a combined analytical and experimental study to examine the response of a model building with friction dampers under earthquake excitations. The results showed that the increase of overall damping caused significant reduction in the maximum deformations of the structures. Montuori et al. [23] proposed a seismic design procedure of braced frames equipped with friction dampers based on theory of plastic mechanism control in order to guarantee the development of a global type mechanism involving all the friction dampers equipping the structure. In another study Mualla and Belev 

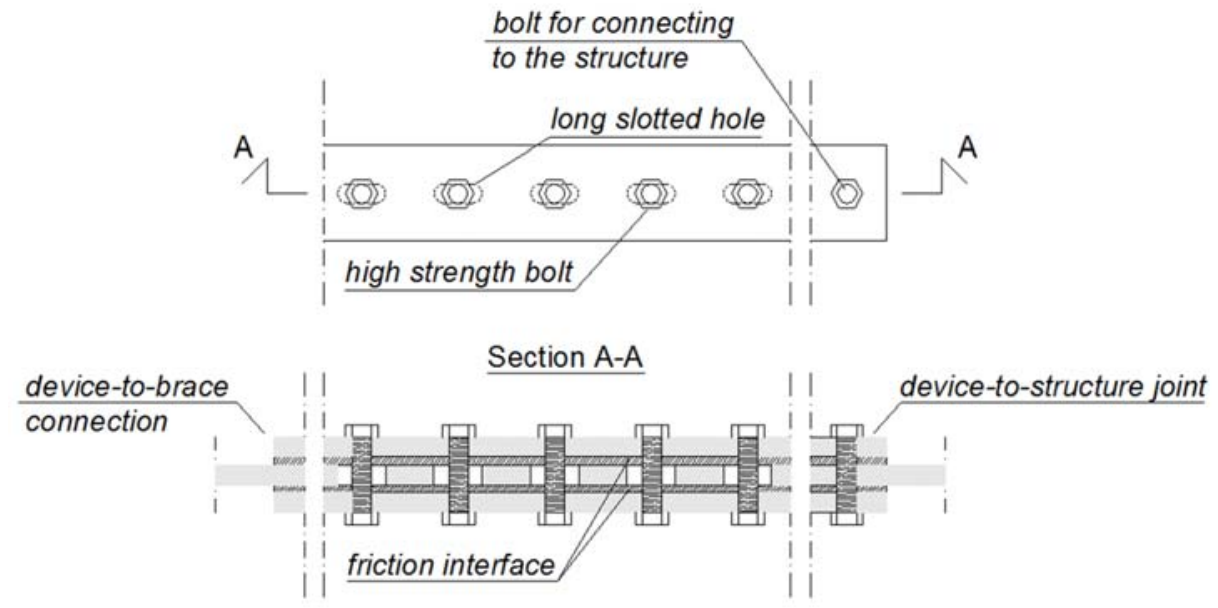

Fig. (1). Schematic view of a friction device according to [26].

[43] proposed a novel rotational friction damper with adjustable slip-moment. Both experimental tests and numerical analyses on a single-storey steel frames incorporating these devices proved the effectiveness of this innovative friction damper. The studies clearly indicated that the developed passive control system provided a viable alternative to the conventional ductility-based earthquake-resistant design. Recently, the use of the friction dampers has been also suggested to equip beam-to-column connections in MRFs to prevent their damage $[45,46]$.

The results from both experiments and analyses obtained in literature and described above have demonstrated that friction-based passive control methods are effective to improve the inelastic response of structures under a seismictype action. This consideration motivated the study presented hereinafter. The main objectives of this study are (i) to examine the potential effectiveness of friction damped braces in order to improve the seismic response of an existing steel moment resisting frame, and (ii) to investigate the seismic demand acting on the devices to derive proper design criteria to guarantee adequate performance at each performance level. To these aims, the overall seismic performance has been analysed through static and dynamic nonlinear analyses against the seismic hazard levels corresponding to probabilities of exceedance of $2 \% / 50$ years and $10 \% / 50$ years.

\section{DESIGN AND MODELLING ASSUMPTIONS OF FRAMES}

\subsection{Original Frame}

The case study is a six storey residential building with a rectangular plan, $31.00 \mathrm{~m} \times 24.00 \mathrm{~m}$. The storey height is equal to $3.50 \mathrm{~m}$ with exception of the first floor, which is $4.00 \mathrm{~m}$ high. The primary seismic resistant system is characterized by few bays perimetric MRFs, as shown in Fig. (2), which are integrated with two additional MRFs in the transversal direction $(\mathrm{Y})$. The remaining parts are designed to resist vertical loads only. The horizontal diaphragms are made of composite slabs with profiled steel sheetings supported by the hot rolled "I-shaped" beams. The composite action is inhibited for all beams belonging to the MRFs because the shear connectors are applied only on the beams of the gravity load designed bays. Moreover, in the moment- resisting parts a gap was kept from both sides of both column flanges, or from other protruding elements associated with the beam-to-column joints, and the structural slab.

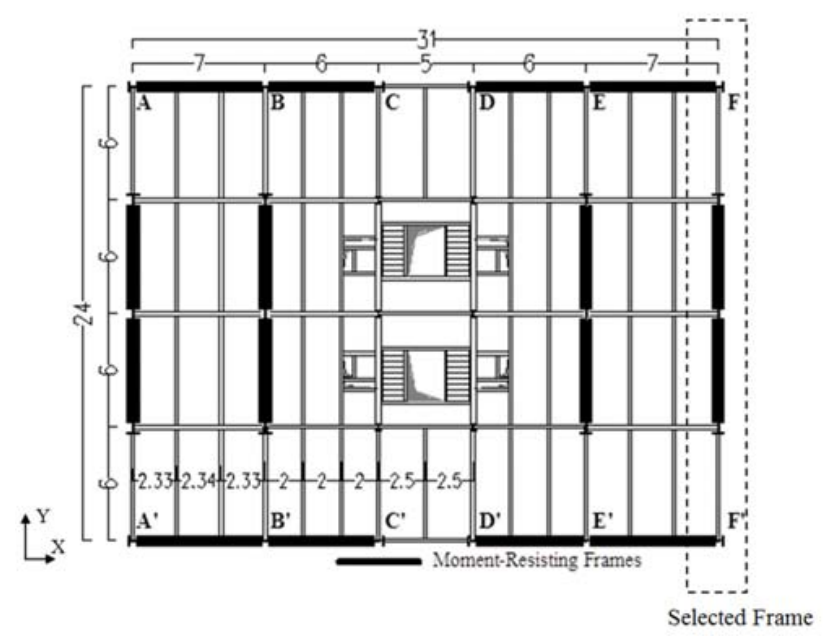

Fig. (2). Structural plan of the steel building under investigation.

The structure was designed in accordance with Eurocode 3 [47] and 8 [48]. Steel grade S275 is used for the beams and columns in the building. For what concerns the seismic action, a reference peak ground acceleration equal to $\mathrm{a}_{\mathrm{gR}}=$ $0.25 \mathrm{~g}$ (being $\mathrm{g}$ the gravity acceleration), a type $\mathrm{C}$ soil and a type 1 spectral shape according to EC8 have been assumed.

In order to investigate the efficiency of friction devices for seismic upgrading of moment resisting framed buildings, the external frame in the $\mathrm{Y}$ direction of the building was selected as the original frame (OF) and the analyses were carried out for this frame system. The OF structural members are depicted in Fig. (3a).

The numerical analyses were carried out using SAP 2000 ver. 14.0 [49]. For modelling the nonlinear behaviour of the structural members, lumped plasticity approach was utilized and the nonlinearity was taken into account by adopting plastic hinges with hysteretic relationships based on FEMA 356 [50]. P- $\Delta$ effects were accounted for by modelling a leaning column that carries the gravity loads in the building 
not directly acting on the moment frame. This additional column is connected to the moment frame using rigid links with pinned joints at each end. In addition, at each level this column is hinged at both top and bottom. This schematization allows inducing only additional overturning moment from the lateral displacement.

\subsection{Friction Damped Braced Frame}

The friction damped braces (FDBs) examined within this study were formerly analysed and tested by Pall and Marsh [30]. Both static and dynamic tests on many sliding elements with different surface treatments showed that this type of damper can guarantee a reliable and repeatable performance with rectangular hysteresis loops and negligible fade over many cycles. However, the effectiveness of this type of device is mainly due to the proper threshold value of frictional forces (namely the slip load) that the damper can experience once the slipping is activated, because it is directly correlated to the dissipated energy. Indeed, if slip load is selected as too low, then the energy dissipation would be small even in case of very large slip movements. On the other hand, if the slip load is selected as too high, then no energy dissipation would be provided by the friction device because no slipping could occur under the seismic actions. Therefore, in the former case, the structure responds as it does without friction damped braces, in the latter case, the structure responds as it does with conventional braces [51].

In order to establish the proper entity of the slip loads, in the examined case study the friction devices were designed in order to satisfy different performance at each seismic hazard level: i) at $10 \% / 50$ years the FDBF should behave in elastic field; ii) at $2 \% / 50$ years the additional dampers have to control the interstorey drift ratio demand within $1.5 \%$ of the storey height which should corresponds to very limited structural damage [52]. To achieve these goals an iterative procedure based on the use of capacity spectra has been adopted as illustrated in [12]. In particular, the response of the frame equipped with FDBs can be schematically idealized as a simple system consisting of two nonlinear springs connected in parallel. This implies that the FDB stiffness and strength should be chosen to limit the demand on the structure such that the system displacement demand at the performance point for the design seismic hazard level is less than or equal the yield displacement of the MRF. The plots showing the performance points obtained for both OF and FDBF at the two design seismic hazard levels are given in (Fig. 4), where it can be directly observed that the design objective at $10 \% / 50$ years is satisfied, namely the seismic displacement demand of bi-linearized FDBF is smaller than the yield displacement of the OF bilinear response curve (see Fig. 4a). However, it should be noted that the obtained target performance implies that some minor damage occur in the actual pushover curve of FDBF. Analysing the response at that level of roof displacement, it was observed that although some plastic hinges form at lower storeys, very small plastic rotations can be recognized (e.g. lesser than $0.4 \%$ ), which corresponds to a negligible residual drifts and easy refurbishment after earthquake.

Therefore, applying this approach twelve single tensioncompression diagonal bracings with friction devices of 500 $\mathrm{kN}$ slip load capacity were designed. The design slip load corresponds to $28 \%$ of the average storey seismic weight. The distribution of these devices into the frame is shown in Fig. (3b).

The hysteretic response of the braced dampers was simulated by means nonlinear spring characterized by Bouc-Wen force-displacement relationship with the exponent equal to 10 , in order to have a sharp transition from the elastic to the post-yielding regime, and a ratio of post-yield stiffness-toelastic stiffness equal to zero because no hardening can be experienced by this type of device.

For what concerns the bracing elements it is well known that the simulation of cyclic buckling has a crucial role to carry out reliable seismic analyses of braced structures [5357]. However, in the presented study, the nonlinear behaviour of the bracing elements was not accounted for, because these elements have been designed to avoid buckling under the maximum capacity of the friction device.

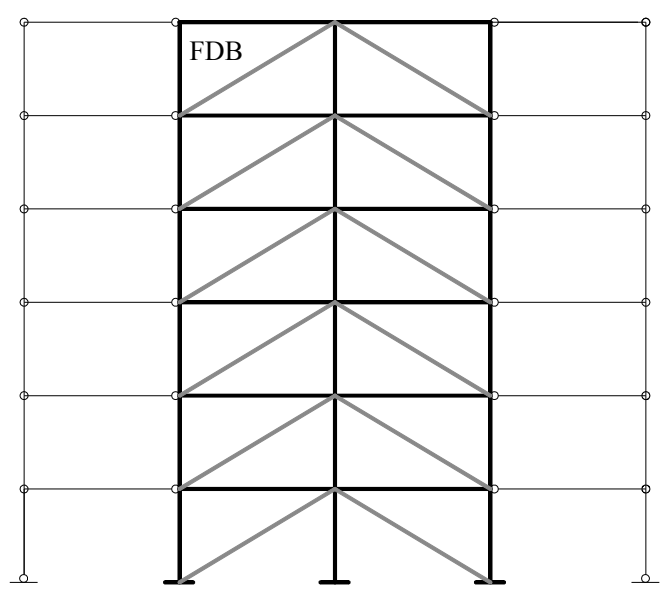

b)

Fig. (3). Elevation view of the a) original frame (OF) and b) friction damped braced frame (FDBF). 


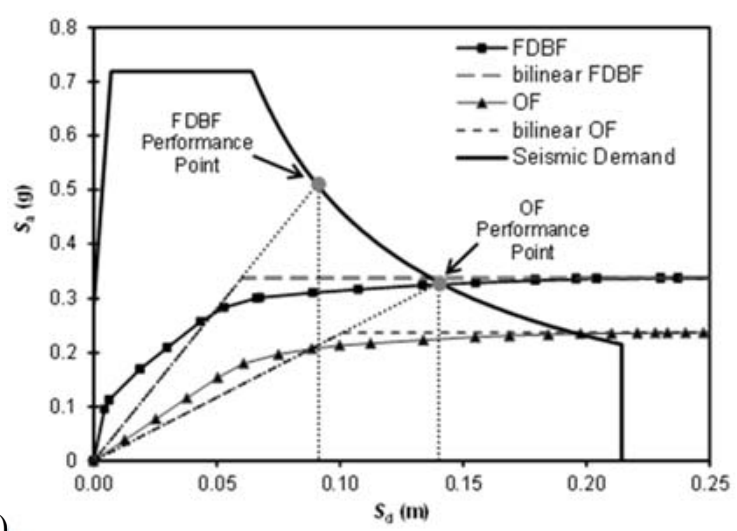

a)

Fig. (4). Acceleration displacement response spectrum and capacity curves for of and FDBF: a) 10\%/50 years and b) $2 \% / 50$ years.

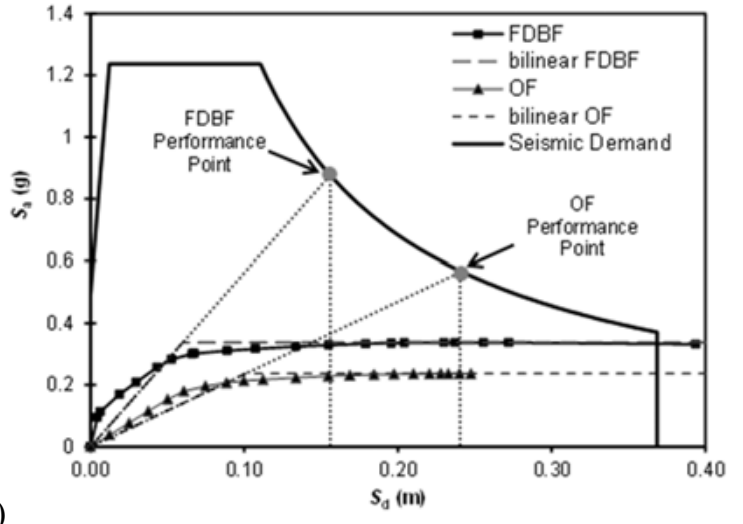

b)

\subsection{Ground Motion Accelerations}

Two sets of natural earthquake acceleration records were used to carry out the nonlinear time history analyses of investigated structures. The signals were obtained from the PEER Ground Motion Database [58] and selected to match the elastic acceleration spectra of EC8 [48] corresponding to two seismic hazard levels (i.e. $10 \%$ probability of exceedance in 50 years, and $2 \%$ probability of exceedance in 50 years). The comparison between the design code spectra and $5 \%$ damped acceleration response spectra of the natural ground accelerations are given in Fig. (5). The properties of the selected natural ground motion accelerations such as the magnitude $\left(\mathrm{M}_{\mathrm{w}}\right)$, the peak ground acceleration (PGA), the peak ground velocity (PGV), peak ground displacement (PGD), the type of mechanism and the soil properties of the registration site are summarized in Table $\mathbf{1}$.

In addition, it should be noted that each record was fictitiously extended by 10 seconds at zero acceleration in order to allow accounting for 10 seconds of free vibrations around the final post-quake configuration, which are necessary to calculate the residual inter-storey drift ratios from the nonlinear time history analyses.

\section{RESULTS AND DISCUSSION}

The seismic response of the structures obtained from nonlinear time history analyses was investigated in terms of maximum inter-storey drift distribution through the height of the structure, storey drift time histories, maximum storey accelerations observed in each storey, residual drifts of the structures, displacement demand of the friction devices.

Figs. (6) and (7) depict the maximum inter-storey drift ratios for the examined frames. As it can be easily recognized the structure equipped with friction devices experienced the lower displacement demand. Indeed, for the $10 \% / 50$ years earthquakes the average maximum inter-storey drift ratio is about $0.67 \%$ for $\mathrm{OF}$, while about $0.17 \%$ for FDBF with the structure in elastic field, thus confirming the fulfilment of the first design objective. Also in case of very rare earthquakes a significant reduction of drift demand can be observed in the frame with dampers. In particular, the average maximum inter-storey drift ratio is about $1.1 \%$ for $\mathrm{OF}$, while about $0.55 \%$ for FDBF hence smaller than $1.5 \%$ assumed as design performance. These results confirm that
FDBs are very effective in reducing the inter-storey drift demand. Moreover, as clearly observed in the figures, the use of FDBs tends to distribute the drift demand more uniformly along the height of the frame.

The time history response of the fourth storey lateral drift ratios of the original frame and friction damped braced frame, under the set of earthquake accelerations with $2 \%$ probability of exceedance in 50 years, are given as an example in Fig. (8). The response time histories shown in this figure also confirm the effectiveness of friction devices in decreasing the lateral displacement demands of the original frame.

In order to assess the efficiency of the examined device to limit the non-structural damage the peak storey accelerations were also monitored. Non-structural components in buildings, which are categorized as drift sensitive and acceleration sensitive, include a large variety of different architectural, mechanical and electrical components such as parapets, cabinets, ornaments, general mechanical, manufacturing and process machinery, lighting fixtures, contents of the buildings etc. [59]. The non-structural components, which constitute the major portion of the economic value of the buildings [60-62], are generally acceleration sensitive components. Therefore, they are mainly damaged due to the large floor acceleration demands under the seismic effects. The profile of maximum storey accelerations are plotted in Figs. (9) and (10). For the first set of records, it was observed that with the addition of friction devices into the system, the maximum storey acceleration responses were reduced on average of about $11 \%$. On the other hand, for the second set of signals friction device reduced the average storey acceleration about $3 \%$ due to the large intensity of the earthquake records.

For the assessment of existing structures, the current performance based seismic evaluation methods use the peak inter-storey drift and storey acceleration demand of the structures. In these methods, it is accepted that the damage level to the structural components are associated with the peak inter-storey drift ratio while the damage level to the nonstructural components correlated with peak floor acceleration and peak inter-storey drift ratio [63]. However, the postearthquake reconnaissance reports showed that the maximum residual drift demand of structures is as important as the maximum transient drift and floor acceleration demand of structures [63-65]. Rosenblueth and Meli [64] reported that 


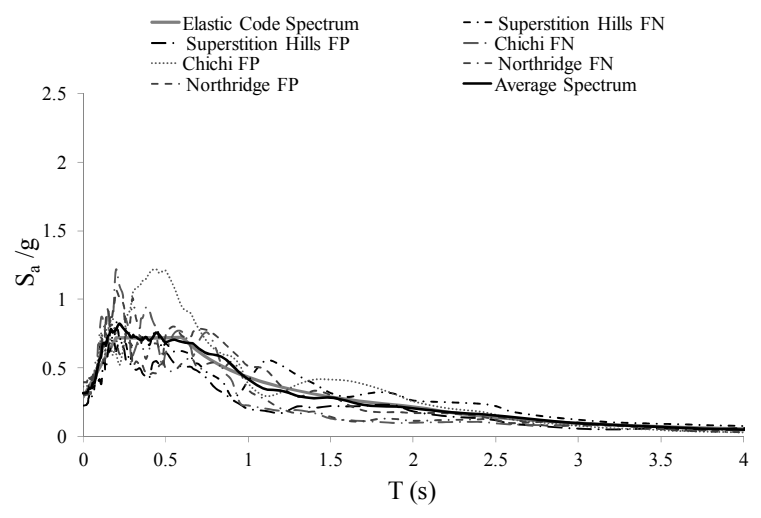

a)

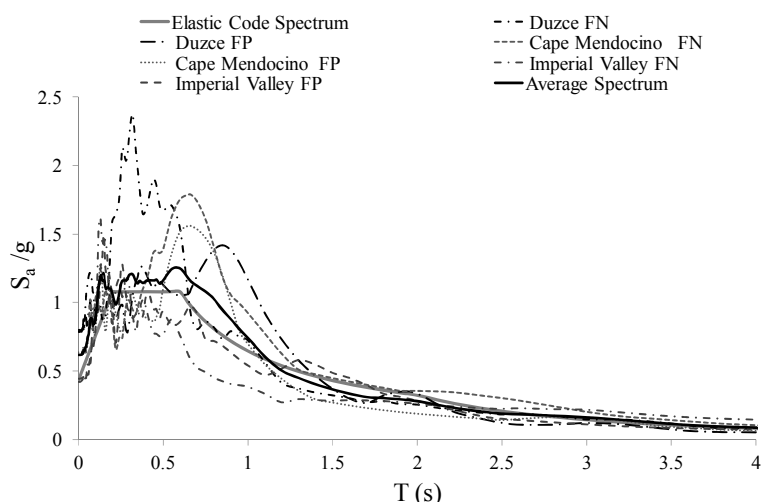

b)

Fig. (5). 5\% damped acceleration response spectra of the ground motions compatible with seismic hazard level of a) $10 \%$ probability of exceedance in 50 years and b) $2 \%$ probability of exceedance in 50 years.

Table 1. Properties of the ground motion accelerations.

\begin{tabular}{|c|c|c|c|c|c|c|c|c|}
\hline Seismic Hazard Level & Earthquake Record & Year & Magnitude $\left(M_{w}\right)$ & Mechanism & $\mathrm{V}_{\mathrm{s} 30}(\mathrm{~m} / \mathrm{s})$ & PGA (g) & PGV $(\mathrm{cm} / \mathrm{s})$ & PGD (cm) \\
\hline \multirow{6}{*}{ 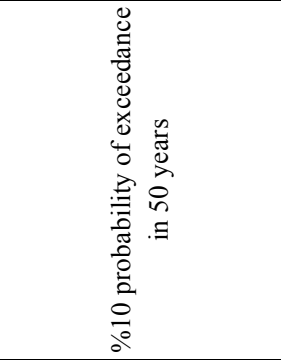 } & Superstition Hills-FN & 1987 & 6.54 & Strike-Slip & 192.1 & 0.31 & 51.89 & 22.25 \\
\hline & Superstition Hills-FP & 1987 & 6.54 & Strike-Slip & 192.1 & 0.22 & 36.13 & 10.64 \\
\hline & Chi Chi -FN & 1999 & 6.2 & Strike-Slip & 553.4 & 0.31 & 31.79 & 9.24 \\
\hline & Chi Chi-FP & 1999 & 6.2 & Strike-Slip & 553.4 & 0.36 & 40.43 & 9.14 \\
\hline & Northridge-FN & 1994 & 6.69 & Reverse & 308.6 & 0.30 & 25.71 & 6.09 \\
\hline & Northridge-FP & 1994 & 6.69 & Reverse & 308.6 & 0.39 & 32.68 & 9.39 \\
\hline \multirow{6}{*}{ 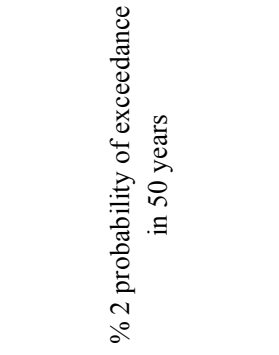 } & Duzce-FN & 1999 & 7.14 & Strike-Slip & 326 & 0.79 & 54.75 & 22.71 \\
\hline & Duzce-FP & 1999 & 7.14 & Strike-Slip & 326 & 0.78 & 62.51 & 13.52 \\
\hline & Cape Mendocino -FN & 1992 & 7.01 & Reverse & 712.8 & 0.61 & 81.87 & 25.48 \\
\hline & Cape Mendocino-FP & 1992 & 7.01 & Reverse & 712.8 & 0.63 & 60.41 & 26.03 \\
\hline & Imperial Valley-FN & 1979 & 6.53 & Strike-Slip & 202.3 & 0.42 & 59.59 & 38.73 \\
\hline & Imperial Valley-FP & 1979 & 6.53 & Strike-Slip & 202.3 & 0.44 & 51.38 & 27.81 \\
\hline
\end{tabular}

a)

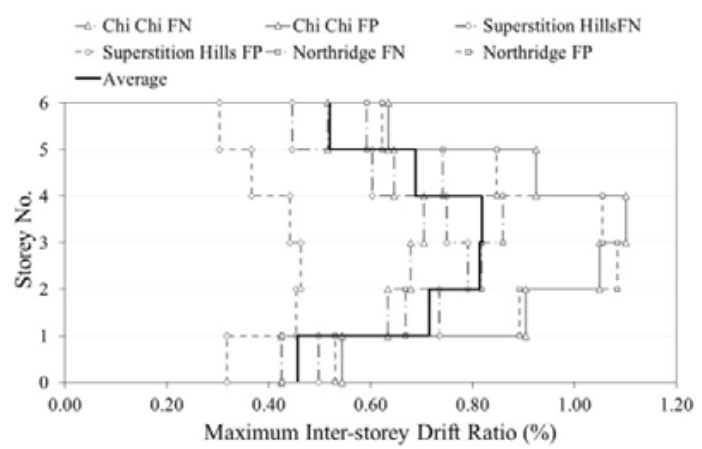

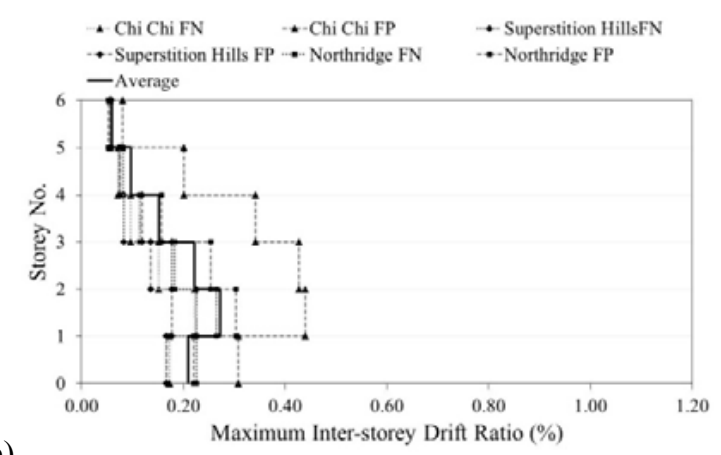

b)

Fig. (6). Maximum inter-storey drift of the a) OF and b) FDBF under earthquake accelerations compatible with seismic hazard level of $10 \%$ probability of exceedance in 50 years. 


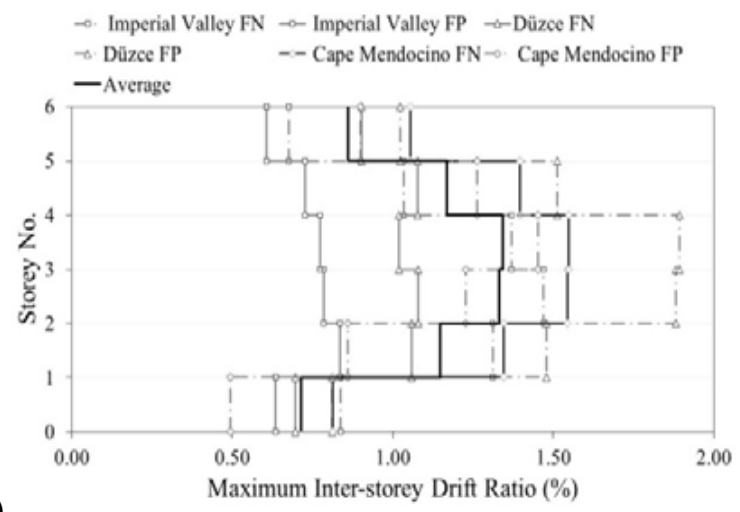

a)

Fig. (7). Maximum inter-storey drift of the a) OF and b) FDBF under earthquake accelerations compatible with seismic hazard level of $2 \%$ probability of exceedance in 50 years.
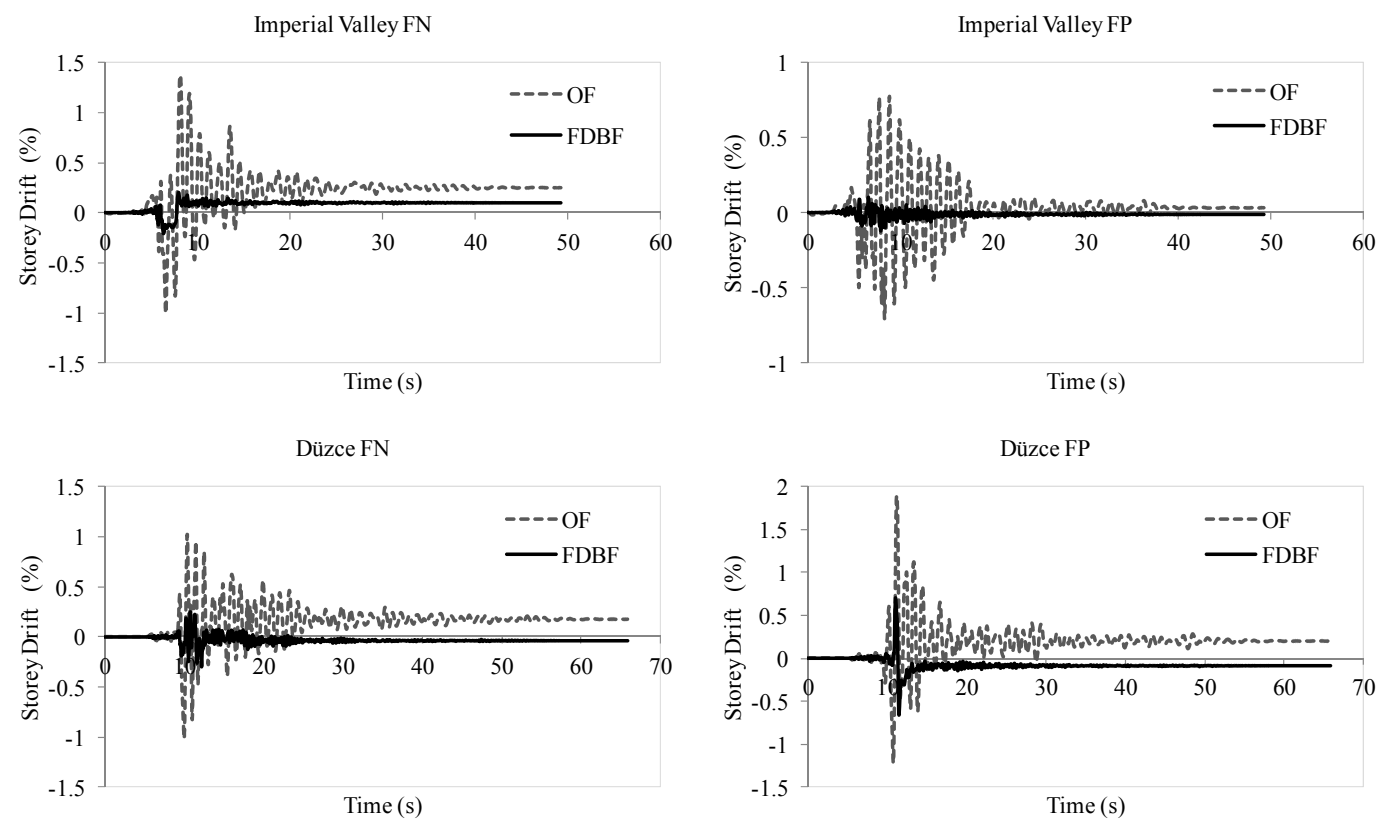

Cape Mendocino FN

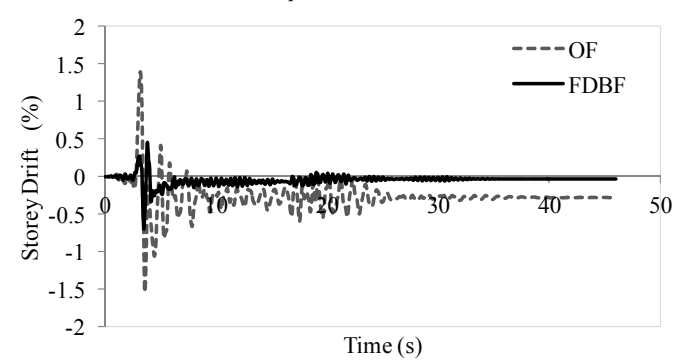

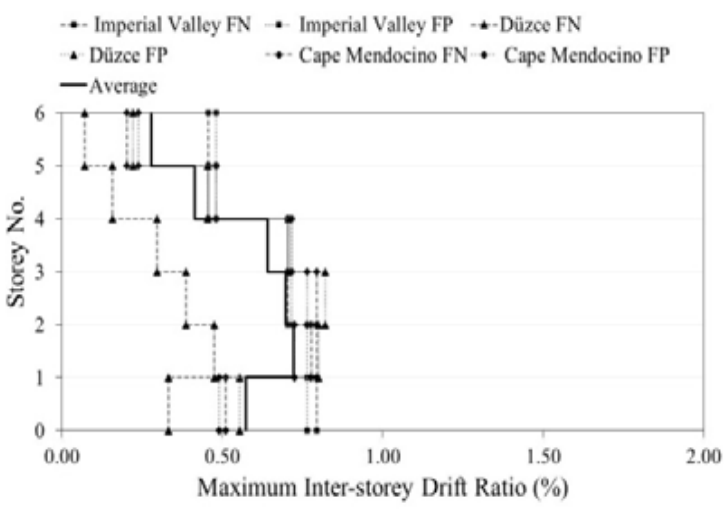

b)

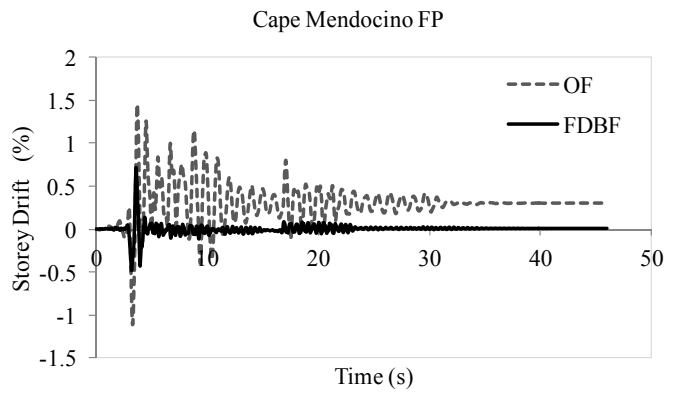

Fig. (8). $4^{\text {th }}$ storey drift time history under earthquake accelerations compatible with seismic hazard level of $2 \%$ probability of exceedance in 50 years.

many reinforced concrete structure that suffered large permanent displacements could not be repaired or retrofitted because of the technical difficulties and demolished. In the report of Okada et al. [65], they presented that after 1995 Hyogo-Ken Nambu earthquake, several low-rise buildings having sufficient deformation capacity experienced large residual deformations and light structural damage. Therefore, residual drift demands of structures constitute another important parameter for seismic response assessment of the structures, especially for all competent authorities devoted to decide about repairing or demolishing a structure after a strong earthquake. In order to examine the effectiveness of friction devices in reducing the residual drift demand, the maximum residual drifts observed in the frame with and without 

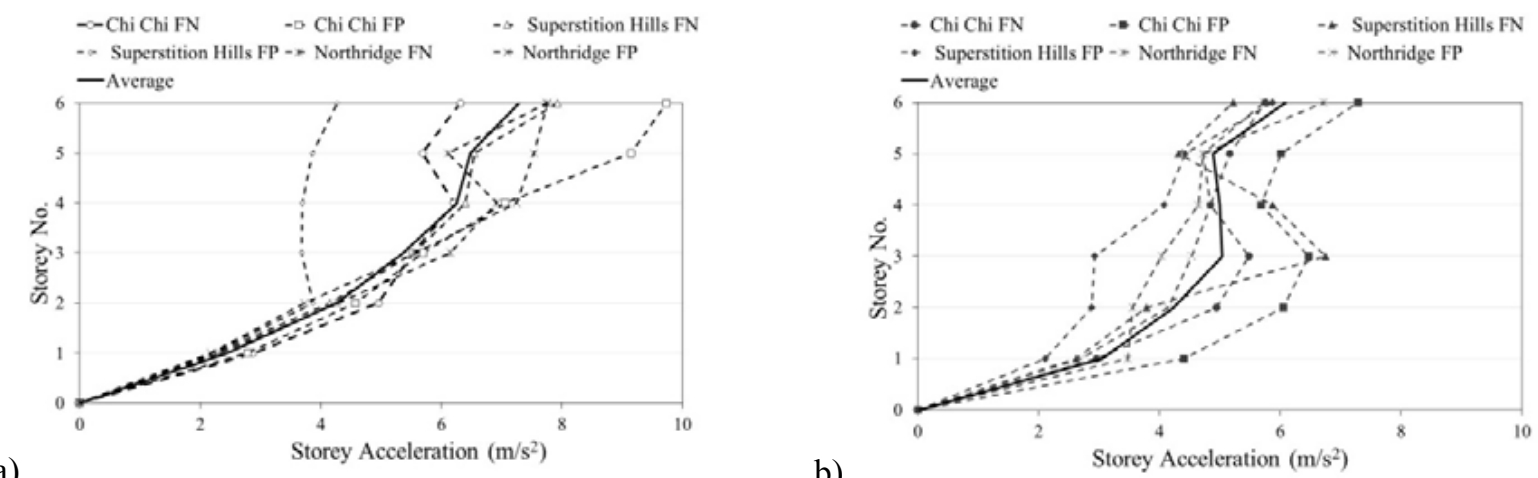

Fig. (9). Maximum storey accelerations observed for a) OF and b) FDBF under earthquake accelerations scaled for the seismic hazard of $10 \%$ probability of exceedance in 50 years.

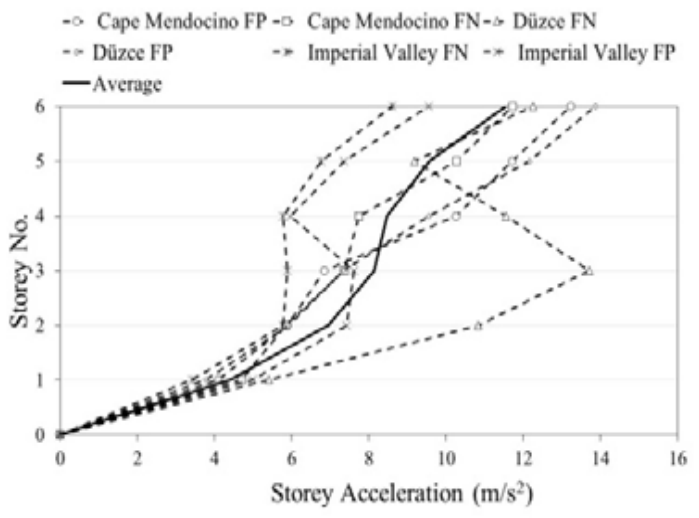

a)

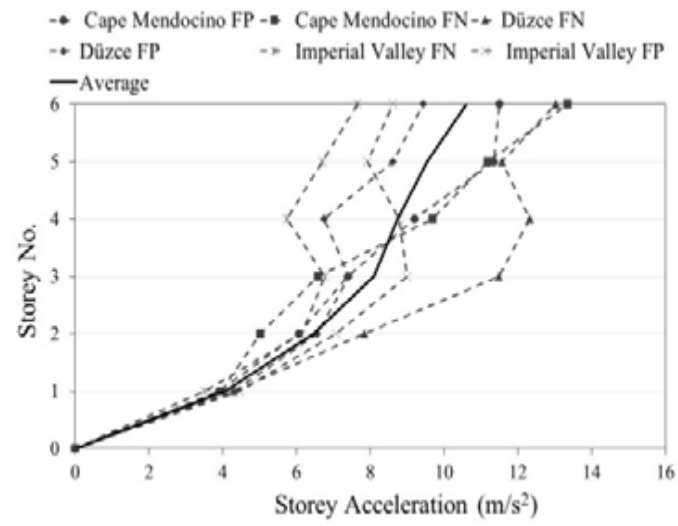

b)

Fig. (10). Maximum storey accelerations observed for a) OF and b) FDBF under earthquake accelerations scaled for the seismic hazard of $2 \%$ probability of exceedance in 50 years.

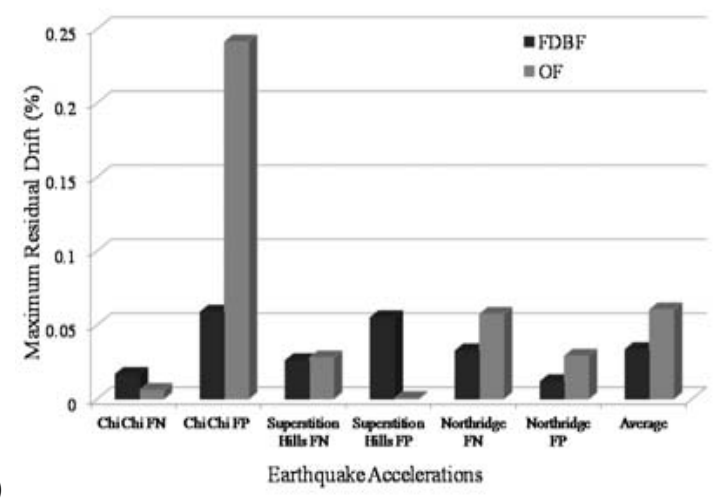

a)

Fig. (11). Residual drifts of OF and FDBF under earthquake accelerations compatible with seismic hazard level of a) $10 \%$ probability of exceedance, b) $2 \%$ probability of exceedance in 50 years.

friction device when subjected to earthquakes with $10 \%$ and $2 \%$ probability of exceedance are given in Fig. (11). It was observed that the use of friction dampers generally reduces the residual drift demand of the frame, and this reduction is much pronounced under the earthquake accelerations compatible with the seismic hazard level of 2\%/50 years. Considering this seismic hazard level, the use of friction dampers decreased the residual demand of the original frame by more than $39 \%$, up to $94 \%$ depending mainly on the earthquake acceleration. When subjected to earthquakes with 10\% / 50 years, it was observed that the frame with friction dampers had residual drift less than $0.06 \%$. Furthermore, the results of the displayed response time histories as shown in (Fig. 8) proved the beneficial effect of friction devices in reducing the residual drifts. 

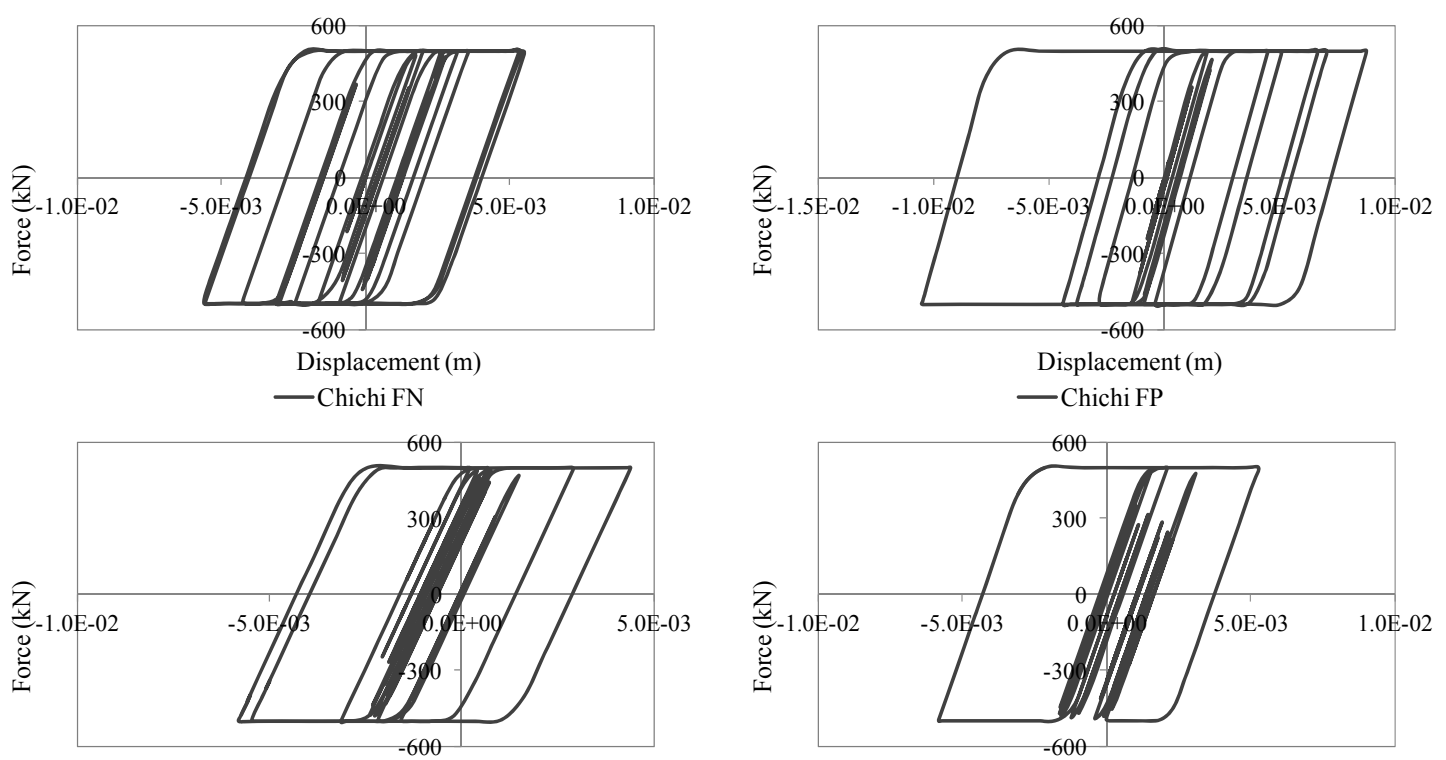

Displacement (m)

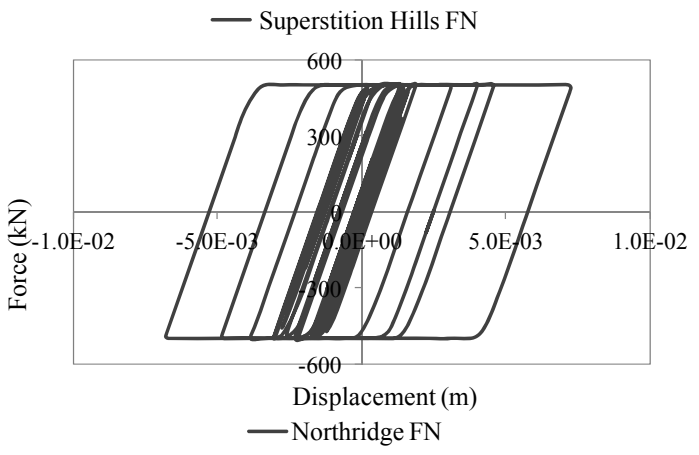

Displacement (m)

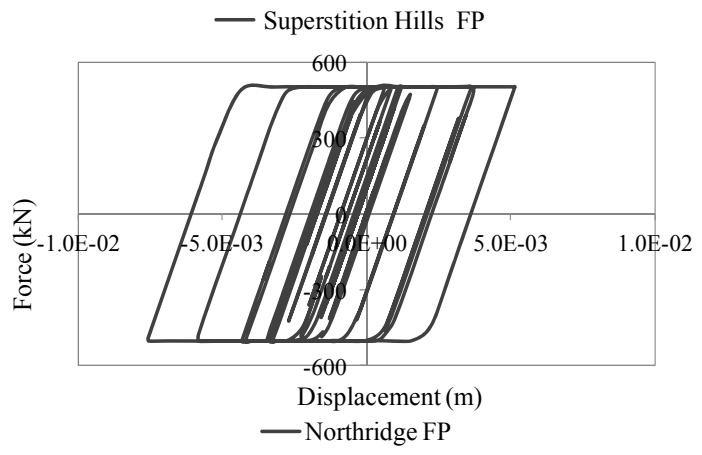

Fig. (12). Hysteretic behaviour of the friction dampers located in the first floor under earthquake accelerations compatible with the seismic hazard of $10 \%$ probability of exceedance in 50 years.

The hysteresis loops of the friction devices located at the first floor of the frame when subjected to the two sets of ground motions are given in Figs. (12) and (13). As illustrated in Fig. (12), the maximum slip displacement demand of the friction device was obtained as $11 \mathrm{~mm}$ under Chi-Chi FP earthquake among the first set of ground motions. When subjected to second set of ground motions compatible with the seismic hazard level of $2 \%$ probability of exceedance in 50 years, the maximum slip displacement demand of the friction device was attained as $18 \mathrm{~mm}$ under Düzce FP earthquake acceleration. The slip displacement demands of the friction devices were in the range of 5.6 to $11 \mathrm{~mm}$ under the earthquakes with $10 \%$ exceedance probability while they varied in between 7.5 and $18 \mathrm{~mm}$ under the earthquakes with $2 \%$ exceedance probability in 50 years. It is important to underline that such displacement demands can be very easily accommodated by governing the stroke of the friction dampers.

\section{CONCLUSIONS}

The analytical study described in this paper examined the effectiveness of friction damped diagonal tensioncompression braces in enhancing the seismic behaviour of an existing steel moment resisting frame designed according to
EC8. The conclusions inferred from this analytical study are summarized below:

- Friction damped braces allow reducing the seismic interstorey drift demand of the original frame. In the examined cases, under the earthquake accelerations with $2 \%$ probability of exceedance in 50 years, friction damped braces reduced the average inter-storey drift demand of about $50 \%$.

- When the inter-storey drift demand of the each frame was examined comparatively, it was observed that the friction damped braced frame had more uniform inter-storey drift distribution along the height of the frame.

- The damage level of acceleration sensitive non-structural components are generally dependent on peak floor accelerations. The presence of FDBs showed a reduction of peak storey acceleration, especially under earthquake accelerations with $10 \%$ probability of exceedance in 50 years.

- The nonlinear time history analyses showed that a significant reduction of the residual inter-storey drift ratios in the structure equipped with FDBs. In particular, when subjected to earthquakes compatible with seismic hazard level of $2 \%$ probability of exceedance in 50 years, the 

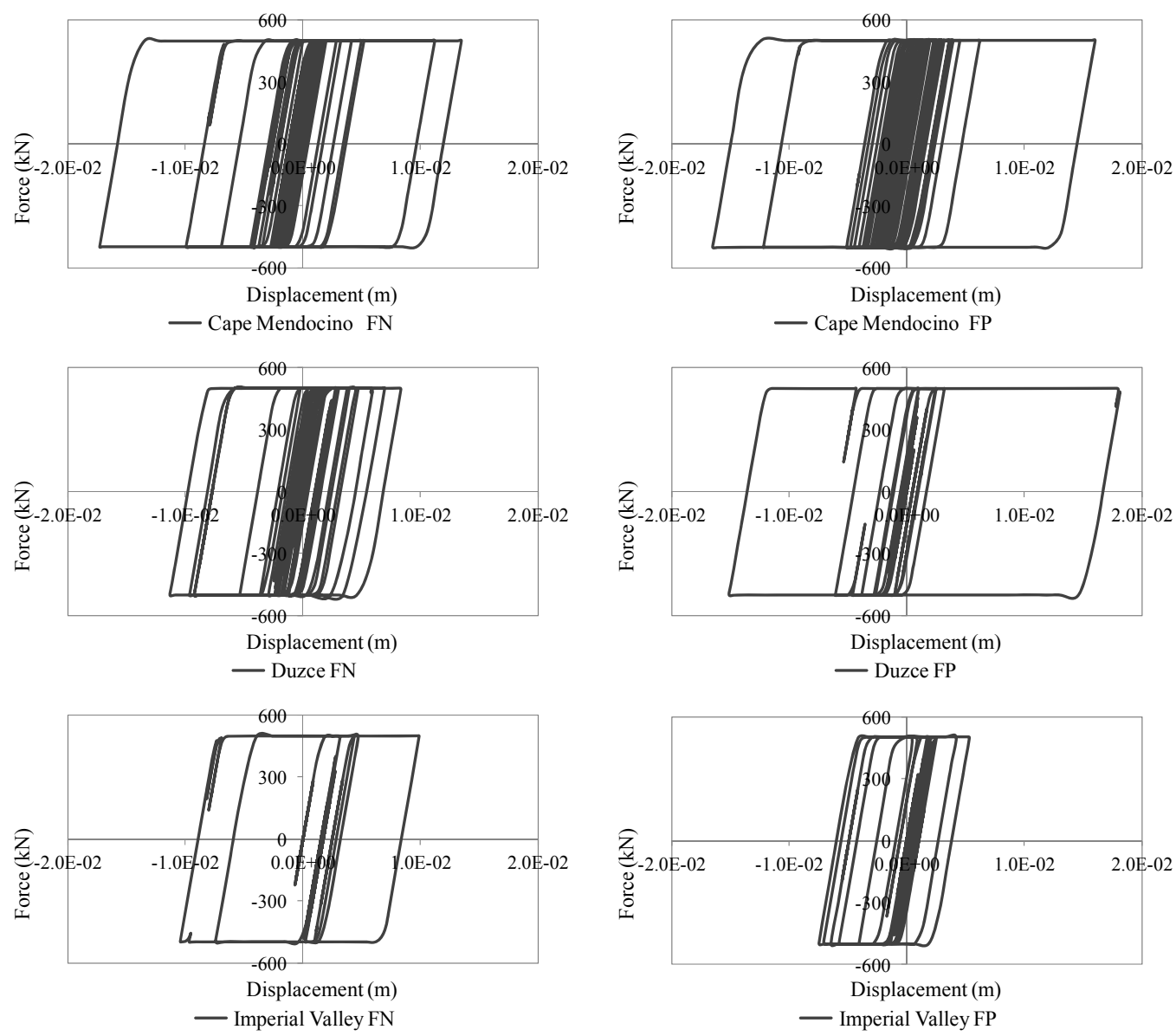

Fig. (13). Hysteretic behaviour of the friction dampers located in the first floor under earthquake accelerations compatible with the seismic hazard of $2 \%$ probability of exceedance in 50 years.

average residual drift value of $0.24 \%$ for the original frame decreased to $0.06 \%$ for the friction damped braced frame.

- In the design of the friction devices, there are two key parameters, one is the slip load and the other one is the required slip displacement. In this study, the slip load of the friction damper was taken as $28 \%$ of the average storey seismic weight. From the analysis, it was found that the maximum slip distance required for this device is about $18 \mathrm{~mm}$ under these sets of ground motion accelerations. Such demands can be easily accommodated by properly designing the stroke of the friction dampers.

\section{CONFLICT OF INTEREST}

The authors confirm that this article content has no conflict of interest.

\section{ACKNOWLEDGEMENTS}

Declared none.

\section{REFERENCES}

[1] FEMA 350, "Recommended Seismic Design Provisions for New Moment Frame Buildings Report," Federal Emergency Management Agency, Washington DC, 2000.
[2] M. Nakashima, K. Inoue, and M. Tada "Classification of damage to steel buildings observed in the 1995 hyogoken-nanbu earthquake," Engineering Structures, vol. 20, pp. 271-81, 1998.

[3] E. Watanabe, K. Sugiura, K. Nagata, and Y. Kitane, "Performances and damages to steel structures during 1995 hyogoken-nanbu earthquake," Engineering Structures, vol. 20, pp. 282-90, 1998.

[4] R. Tremblay, P. Timler, M. Bruneau, and A. Filiatrault, "Performance of steel structures during the 1994 northridge earthquake," Journal of Civil Engineering, vol. 22, pp. 338-60, 1995.

[5] N. Youssef, D. Bonowitz, and J. Gross, A Survey of Steel MomentResisting Frame Buildings Affected by the 1994 Northridge Earthquake, Research report no. NISTIR 5625. Gaithersburg (MD, USA): National Institute of Science and Technology (NIST), 1995.

[6] A.B. Climent, "Influence of hysteretic dampers on the seismic response of reinforced concrete wide beam-column connections", Engineering Structures, vol. 28, pp. 580-92, 2006.

[7] F.M. Mazzolani, G. Della Corte, and M. D'Aniello, "Experimental analysis of steel dissipative bracing systems for seismic upgrading”, Journal of Civil Engineering and Management, vol. 15, pp. 719, 2009.

[8] M. Bosco, and E.M. Marino, "Design method and behavior factor for steel frames with buckling restrained braces", Earthquake Engineering \& Structural Dynamics, vol. 42, pp. 1243-63, 2013.

[9] C. Durucan, and M. Dicleli, "Analytical study on seismic retrofitting of reinforced concrete buildings using steel braces with shear link”, Engineering Structures, vol. 32, pp. 2995-3010, 2010.

[10] J. A. Oviedo-Amezquita, M. Midorikawa, and T. Asari. "Earthquake response of ten-story story drift-controlled reinforced concrete frames with hysteretic dampers", Engineering Structures, vol. 32, pp. 1735-46, 2010.

[11] M. D'Aniello, G. Della Corte, and F.M. Mazzolani, "Seismic upgrading of rc buildings by buckling restrained braces: Experimental 
Results vs. Numerical Modeling", In: Proceedings of STESSA Conference 2006, Japan, 14-17 August 2006.

[12] M. D'Aniello, G. Della Corte, and F.M. Mazzolani, "Experimental tests of a real building seismically retrofitted by special bucklingrestrained braces", In: Proceedings of 2008 Seismic Engineering Conference Commemorating the 1908 Messina and Reggio Calabria Earthquake. Book Series: AIP Conference Proceedings, vol. 1020, pp. 1513-20, 2008.

[13] G. Della Corte, M. D'Aniello, and R. Landolfo, "Field testing of all-steel buckling restrained braces applied to a damaged reinforced concrete building", Journal of Structural Engineering, ASCE DOI: 10.1061/(ASCE)ST.1943-541X.0001080, 2014.

[14] M. D’Aniello, G. Della Corte, and F.M. Mazzolani, "Seismic Upgrading of RC Buildings by Eccentric Braces: Experimental Results vs. Numerical Modeling", In: Proceedings of STESSA Conference 2006, Japan, 14-17 August 2006.

[15] E. Barecchia, M. D’Aniello, G. Della Corte, and F.M. Mazzolani, "Eccentric bracing in seismic retrofitting: from full scale tests to numerical FEM analysis". In: Proceedings of International Conference On Metal Structures 2006 "Steel - A New And Traditional Material For Building" Poiana Braşov September 20-22, 2006.

[16] G. Della Corte, M. D'Aniello, and F.M. Mazzolani, "Inelastic response of shear links with axial restraints: Numerical $v s$. analytical results". In: Proceedings of $5^{\text {th }}$ International Conference on Advances in Steel Structures, ICASS, 2007.

[17] G. Della Corte, M. D'Aniello, and R. Landolfo, "Analytical and numerical study of plastic overstrength of shear links", Journal of Constructional Steel Research, vol. 82, pp. 19-32, 2013.

[18] E. M. Güneyisi, and G. Altay, "Seismic fragility assessment of effectiveness of viscous dampers in $\mathrm{R} / \mathrm{C}$ buildings under scenario earthquakes", Structural Safety, vol. 30, pp. 461-80, 2008.

[19] E. M. Güneyisi, "Seismic reliability of steel moment resisting framed buildings retrofitted with buckling restrained braces", Earthquake Engineering and Structural Dynamics, vol. 41, pp. 853-74, 2012.

[20] G. De Matteis, A. Formisano, F.M. Mazzolani, and S. Panico, “ Design of low-yield metal shear panels for energy dissipation". In: Proceedings of the Final Conference of COST Action C12, Innsbruck (Austria), pp. 665-675, 20-22 January 2005,

[21] A. Formisano, A. G. De Matteis, and F.M. Mazzolani, "Numerical and experimental behaviour of a full-scale RC structure upgraded with steel and aluminum shear panels", Computers and Structures, vol. 88, Issue 23-24, pp. 1348-60, 2010.

[22] V. Piluso, R. Montuori, and M. Troisi, "Innovative structural details in MR-frames for free from damage structures", Mechanics Research Communications, vol. 58, pp. 146-56, 2014.

[23] R. Montuori, E. Nastri and V. Piluso, "Theory of plastic mechanism control for the seismic design of braced frames equipped with friction dampers", Mechanics Research Communications, vol. 58, pp. 112-23, 2014.

[24] M. Mirtaheri, A. P. Zandi, S. S. Samadi and H. R. Samani, "Numerical and experimental study of hysteretic behavior of cylindrical friction dampers", Engineering Structures, vol. 33, pp. 3647-56, 2011.

[25] K. W. Mina, J. Y. Seonga, and J. Kim, "Simple design procedure of a friction damper for reducing seismic responses of a single-story structure", Engineering Structures, vol. 32, pp. 3539-47, 2010.

[26] J.D. Morales Ramirez, and L. Tirca "Numerical simulation and design of friction-damped damped steel frame structures", 15 WCEE, Lisboa, 2012, p.10.

[27] M. Latour, V. Piluso, and G. Rizzano, "Experimental analysis on friction materials for supplemental damping devices", Construction and Building Materials, vol. 65, pp. 159-76, 2014.

[28] H.S. Monir, and K. Zeynali, "A modified friction damper for diagonal bracing of structures", Constructional Steel Research, vol. 87, pp. 17-30, 2013.

[29] T. T. Soong, and G.F. Dargush, Passive Energy Dissipation Systems in Structural Engineering, Chichester: John Wiley \& Sons, 1997.

[30] A. S. Pall, and C. Marsh, "Response of friction damped braced frames", Journal of Structural Division, ASCE, vol. 108, pp. 131323, 1982.

[31] Aiken, and S. Kelly, "Earthquake Simulator Testing and Analytical Studies of Two Energy Absorbing Systems for Multi-Storey Structures", Report No. UCB/EERC-90/03, EERC, Berkeley, 1990.
[32] M. C. Constantinou, A. M. Reinhorn, A. S. Mokha, and R. Watson, "Displacement control device for base isolated bridges", Earthquake Spectra, vol.7, pp. 179-200, 1991.

[33] T. F. Fitzgerald, T. Anagnos, M. Goodson, and T. Zsutty "Slotted bolted connections in a seismic design of concentrically braced connections", Earthquake Spectra, vol. 5, pp. 383-91, 1989.

[34] C. E. Grigorian and E. P. Popov, "Slotted bolted connection energy dissipaters", Earthquake Spectra, vol. 9, pp. 491-504, 1993.

[35] D. K. Nims, P. J. Richter, and R. E. Bachman, "The use of the energy dissipation restraint for seismic hazard mitigation", Earthquake Spectra, vol. 9, pp. 467-87, 1993.

[36] A. Filiatrault, and S. Cherry, "Seismic design spectra for friction damped structures", Journal of Structural Division, ASCE, vol. 116, pp. 1334-55, 1990.

[37] C. Li, and A. M. Reinhorn, "Experimental and Analytical Investigation of Seismic Retrofit of Structures with Supplemental Damping: Part II-Friction devices", Technical report NCEER-95-0009, Buffalo (NY), State University of New York at Buffalo, 1995.

[38] A. Filiatrault, and S. Cherry, "Parameters influencing the design of friction damped structures", Canadian Journal of Civil Engineering, vol.16, pp. 753-66, 1989.

[39] P. Colajanni, and M. Papia, "Hysteretic characterization of friction damped braced frames", Journal of Structural Engineering, ASCE, vol. 123, pp. 1020-28, 1997.

[40] U. Dorka, H. J. Pradlwarter, and U. Schue"ller, "Reliability of MDOF-System with Hysteretic Devices", Engineering Structures, vol. 20, pp. 685-91, 1998.

[41] Y. Fu, and S. Cherry, "Simplified Seismic code design procedure for friction-damped steel frames", Canadian Journal of Civil Engineering, vol. 26, pp. 55-71, 1999.

[42] R. Levy, E. Marianchik, A. Rutenberg, and F. Segal, "A Simple approach to the seismic design of friction damped braced mediumrise frames" Engineering Structures, vol. 23, pp. 250-59, 2001.

[43] H. Mualla, and B. Belev, "Performance of steel frames with a new friction damper device under earthquake excitation", Engineering Structures, vol. 24, pp. 365-71, 2002.

[44] S. H. Lee, J. H. Park, S. K. Lee, and K. W. Min "Allocation and slip load of friction dampers for a seismically excited building structure based on storey shear force distribution", Engineering Structures, vol. 30, pp. 930-40, 2008.

[45] M. Latour, V. Piluso, and G. Rizzano, "Experimental analysis of innovative dissipative bolted double split tee beam-to-column connections", Steel Construction, vol. 4, issue. 2, pp. 53-64, 2011.

[46] M. Latour, V. Piluso, and G. Rizzano, "Experimental behaviour of friction t-stub beam-to-column joints under cyclic loads", Steel Construction, vol. 6, issue. 1, pp. 11-18, 2013.

[47] CEN. EN 1993-1-1-Eurocode 3: "Design of Steel Structures. Part 1: General Rules and Rules for Buildings", 2005.

[48] prEN 1998-Eurocode 8: "Design of Structures for Earthquake Resistance. Part 1: General Rules, Seismic Actions and Rules for Buildings", 1998.

[49] "Computers and Structures", Inc., SAP 2000 Advanced 14.0.0., Structural Analysis Program, Berkeley, CA., 2011.

[50] FEMA 356, Prestandard and Commentary for the Seismic Rehabilitation of Buildings, Federal Emergency Management Agency, Washington, DC, 2000.

[51] A. Filiatrault, and S. Cherry, "Seismic design spectra for frictiondamped structures," Journal of Structural Engineering, vol. 116, pp. 1334-55, 1990.

[52] A. Tenchini, M. D'Aniello, C. Rebelo, C.R. Landolfo, L.S. da Silva, and L. Lima, "Seismic performance of dual-steel moment resisting frames", Journal of Constructional Steel Research, pp. 437454, 2014. DOI:10.1016/j.jcsr.2014.06.007

[53] M. D'Aniello, F. Portioli, R. Landolfo, "Modelling issues of steel braces under extreme cyclic actions". In: Proceedings of COSTC26 Final Conference - Naples 16-18 September; pp. 335-341, 2010.

[54] M. D'Aniello, G. La Manna Ambrosino, F. Portioli, and R. Landolfo, "Modelling aspects of the seismic response of steel concentric braced frames", Steel and Composite Structures, An International Journal, Vol. 15, No. 5, pp 539-66, 2013.

[55] M. D’Aniello, G. La Manna Ambrosino, F. Portioli, R. Landolfo, "The influence of out-of-straightness imperfection in PhysicalTheory models of bracing members on seismic performance assessment of concentric braced structures". The Structural Design of 
Tall and Special Buildings, 2014 (published online 20April 2014). DOI: $10.1002 /$ tal.1160.

[56] A. Castaldo, V. Macillo, A. Formisano, L. Fiorino, B. Faggiano, and F. M. Mazzolani, "Evaluation of the Italian seismic code for the design of concentrically v-braced steel structures", In: Proceedings of $7^{\text {th }}$ European Conference on Steel and Composite Structures (EUROSTEEL 2014), Napoli, Italy, 10-12 September 2014, paper n.06-677.

[57] V. Macillo, C. Castaldo, L. Fiorino, A. Formisano, B. Faggiano, and F. M. Mazzolani, "Evaluation of the Italian seismic code for the design of concentrically x-braced steel structures", In: Proceedings of $7^{\text {th }}$ European Conference on Steel and Composite Structures (EUROSTEEL 2014), Napoli, Italy, 10-12 September 2014, paper n.05-693.

[58] PEER. "The Pacific Earthquake Engineering Research Center". User's Manual for the PEER Ground Motion Database Application, University of California, Berkeley, 2011.

[59] HAZUS, "Earthquake Loss Estimation Methodology, Technical Manual", National Institute of Building for the Federal Emergency Management Agency, Washington (DC), 1997.

[60] J. M. Ayers, and T. Y. Sun, "Nonstructural damages, San Fernando, California, earthquake of February 9, 1971 ", U.S. Department of Commerce, National Oceanic and Atmospheric Admin, 1973.
[61] R. V. Whitman, S.-T Hong, and J. Reed, "Damage statistics for high-rise buildings in the vicinity of the San Fernando Earthquake", Report No. 7, Massachusetts Institute of Technology, 1973.

[62] S. S. Rihal. "Performance and behavior of non-structural building components during the Whittier Narrows, California (1987) and Loma Prieta, California (1989) earthquakes: selected case studies", Report No. ATC-29, Processing Seminar and Workshop on Seismic Design and Performance of Equipment and Nonstructural Elements in Buildings and Industrial Structures, Applied Technology Council, Redwood City, California, pp. 119-143, 1992.

[63] J. Ruiz-Garcia, and E. Miranda, "Probabilistic estimation of residual drift demands for seismic assessment of multi-story framed buildings", Engineering Structures, vol. 32, pp. 11-20, 2010.

[64] E. Rosenblueth, and R. Meli, "The 1985 Mexico Earthquake: Causes and Effects in Mexico City", Concrete Internat (ACI), vol. 8, pp. 23-34, 1986.

[65] T. Okada, T. Kabeyasawa, T. Nakano, M. Maeda, and T. Nakamura, "Improvement of seismic performance of reinforced concrete school buildings in Japan Part 1 Damage survey and performance evaluation after the 1995 Hyogo-Ken Nambu earthquake". In: Proceedings of the $12^{\text {th }}$ world conference on earthquake engineering, Paper 2421, 2000.

Received: July 30, 2014

Revised: October 01, 2014

Accepted: October 03, 2014

(C) Güneyisi et al.; Licensee Bentham Open.

This is an open access article licensed under the terms of the Creative Commons Attribution Non-Commercial License (http://creativecommons.org/licenses/by-nc/3.0/) which permits unrestricted, non-commercial use, distribution and reproduction in any medium, provided the work is properly cited. 